Mahyuni, EL. et al. The Pattern Of Safety And Health Work To Prevent Musculoskeletal Disorders...

\title{
THE PATTERN OF SAFETY AND HEALTH WORK TO PREVENT MUSCULOSKELETAL DISORDERS AT WELDING WORKER IN MAHKAMAH STREET MEDAN
}

\author{
Eka Lestari Mahyuni ${ }^{1)}$; Kalsum ${ }^{2)}$; Makmur Sinaga ${ }^{3)}$ \\ 1,2,3 Occupational Safety and Health Department \\ Faculty of Public Health, University of Sumatera Utara
}

\begin{abstract}
The welding worker has a potential risk in their work whereas the posture in welding process was not ergonomic. The fatique or musculoskeletal disorders happened at the welding worker shown by their vertebra disorders and some complaint like feel pain in their bone and muscle. The posture like bending over to the floor or squate position in a long duration would giving the fatique complaint at the last process. The purpose of this research was to implement the pattern of safety and health work as the prevention action for decrease the musculoskeletal disorders. This is an observasional survey by using the handycam to documented the posture and use the Participatory Action Research approach. Nordic body map questionnaire used to present the mapping of musculoskeletal disorders that happened at the welding worker. The results showed the pattern of safety and health work could be implement at the welding worker such as change the posture with welding in standing posture by using the work bench and do the ergonomic relaxation in 2-3 minutes if the worker feel pain in the part of their body, then do the full ergonomic exercises after the work. The result show that the workers feel pain at their knee, waist, hand, back and shoulder after their work. When they implement the ergonomic relaxation or exercises the musculoskeletal disorders are decrease in $67 \%$ than before and feel productive to continue their work. In conclusion, the ergonomic exercise and relaxation could decrease the musculoskeletal disorders at the welding worker in Mahkamah street Medan. Recommended to the host of welding informal industry to arranged their work time for implement the ergonomic exercise in daily to decrease the musculoskeletal disorders at welding process.
\end{abstract}

Key word : welding, posture, musculoskeletal disorders, ergonomic

Corresponding Author:

Eka Lestari Mahyuni

Mobile phone : +6281376287171

Email: eka mahyuni@ymail.com 


\section{INTRODUCTION}

Occupational safety and health is an applied science in every workplace. This application has been regulated in Undang Undang RI No.1 Tahun 1970, concerning work safety, Undang Undang No.14 Tahun 1969 clauses 9 and 10 of the main provisions concerning labor, PERMENAKER No: PER. 02 / MEN 1982 on qualifying welders in the workplace. In general, the achievement of safety and health could not be separated from the role of ergonomic, because ergonomic related to people who work, in addition to the effectiveness and efficiency of work [1,2].

Welding industry is the one of the informal industry sector belonging to Usaha Kecil Menengah (UKM) which still not yet consider the Occupational Safety and Health $(\mathrm{OSH})$ as priority scale. The minimum implementation of OSH generally in UKM covers $91 \%$ of 169,524 entities in Indonesia needed to get serious attention and important of awareness about Occupational Safety and Health. This is necessary because workers in informal sector are very vulnerable to accidents and occupational diseases [3].

Welding is defined as one of the techniques of grafting metal, in practice it is not an easy task because it has a very high physical risk, so that in the process requires special skills and equipment, to did not exposed by accident and health problems. [4.5].

Every work always contained hazards including welding process. The hazard of welding can be distinguished by the nature of its work such as electric machine operation, fire, arc welding radiation, welding fume, explosion and noise. The electromagnetic rays generated from welding are non-ionizing radiation consisting of ultraviolet light with wave lengths of 200-400 nm, visible light with wave length $400-700 \mathrm{~nm}$ and infrared light with wave lengths between 700-1400 $\mathrm{nm}$. This ray has a power of at least 100 watt with a wavelength lies 1064 nanometers. In addition, in the process of welding workers generally show a posture that is not ergonomic and irregular way of working. Ergonomic work posture often occurs due to ergonomic work facilities where workers work in an incorrect position like form a bent posture. $[6,7,8,9]$

The results of the Ministry of Health studies on the profile of health problems in Indonesia showed that about $40.5 \%$ of diseases suffered by workers related to their work. According to a study of 9,482 workers in 12 districts / cities in Indonesia, the health problems experienced by workers are musculoskeletal disease (16\%), cardiovascular (8\%), neurological disorders $(6 \%)$, respiratory problems $(3 \%)$, and EarNose-Throat (1.5\%) [10].

Jalan Mahkamah Medan is one of the centers of welding workshop in Medan City. In each welding process, it is found that a lot of ergonomic work methods are demonstrated from the posture of a squat in long periods of time due to work done on the floor or over the iron pile. Manual handling process also much happening where workers must move the steels that has been ready or will be welded to a certain place.

Based on the results of preliminary survey, showed that the workers who have abnormalities in muscle and skeleton such as lordosis, increased shoulders, kifosis, and hips are sloping. Workers also feel pain on the body such as part of calf, waist, shoulders and hands. Based on the statement, the purpose of this study was to implement a safe and healthy work patterns as an effort to prevent musculoskeletal disorders complaints.

\section{METHOD}

This research was conducted at $\mathrm{Jl}$. Mahkamah Medan which is the center of welding business. Population in this research are all welding worker at 22 workshop of welding with total worker counted 93 persons. The sampling technique was done by purposive sampling and there were 51 
workers willing in this research. This research is an observation research using handycam. In the application of safe and healthy working pattern used Participatory Action Research approach. The

\section{RESULTS AND DISCUSSION}

\section{Overview of Welding Workshop at Jl. Mahkamah Medan}

The welding industry of Jalan Mahkamah Medan is a business belonging to informal sector engaged in the product of cafe tents, fences, canopies and others using iron as base materials. Initially in 1973 on Jl. Mahkamah only stands two metal industries, until in 1995 began to multiply untill now.[11]

The work environment of each welding workshop looks homogeneous where musculoskeletal complaints felt by the welding workers were obtained using the Nordic Body Map questionnaire. The data obtained were analyzed in descriptively.

each workshop space is filled with stacking iron, open work space and a bit dark and directly related to the outdoor environment. Noise due to grinding or welding process and welding rays that appear either continuously or intermittently could be seen directly because on average almost all workers are done openly without using a curtain or in a special place. The worker also do their work in naturally without using a complete protective device. The welding worker usually only wears black glasses to reduce the glare experienced while welding, but also workers who didn't use any personal protection during their work.

\section{Ergonomics Hazard at Welding Worker JI Mahkamah Medan}

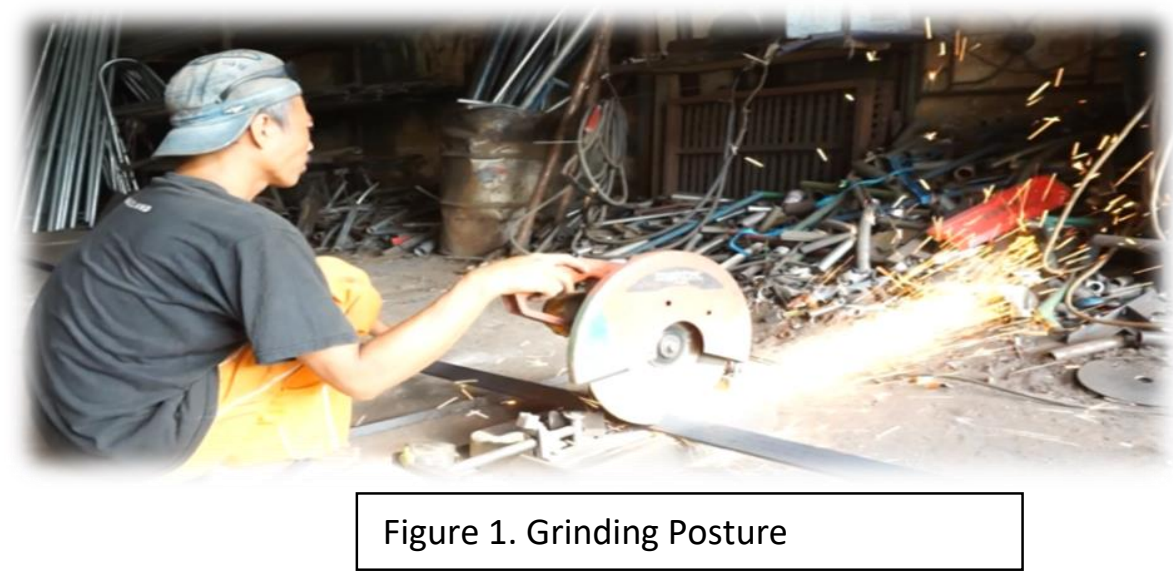

Welding process at Jl. Mahkamah has many risks, especially ergonomic hazards characterized by work postures, layouts, manual handling and working methods. Lay out in welding workshops is difficult to change because the existing room is strived to the maximum extent possible as putting the irons with long or short sizes. To preparation of iron is always placed on the side of the room, so that the work area is dominated in the middle of the room. In this case the stacked conditions are still understandable as long as the distance for passing is filled. 


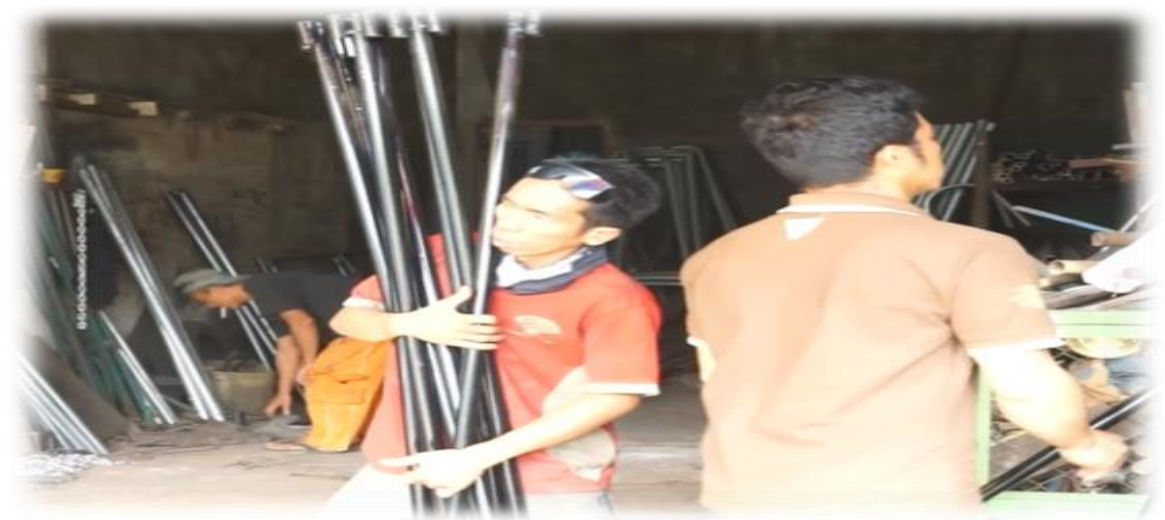

Figure 2. Manual handling

Manual handling often occurs in the welding process where workers must move the material in the form of iron from one place to another for the continuation of each process. The raised iron is also not in the amount of one but it could be with 5-7 iron bars or other shapes of varying weight. When lifting and transporting, the worker shows a bending and non-ergonomic posture. Late bending activity caused by overloading causes spinal injuries and other musculoskeletal disorders [12].

Working posture formed on the welding process varies. The posture that formed on the worker due to human machine relations that occur in a limited area and surrounded by iron piles. Work postures also vary in motion according to the way work happens during the welding process. Work posture is a decisive point in the analysis of welding workers because it is determined by welding skills. If the working posture is incorrect or not ergonomic it may lead to musculoskeletal fatigue and complaints [13].

Welding process begins from the production pattern making by measuring and cutting iron. Cutting of iron by size is done on the floor by using grinding. As a result, the body's posture is not ergonomic like squatting for a long time, squatting while bowing, even half standing with a bent of approximately $90^{\circ}$. Working position that requires squatting by folding both legs close to the body in a long time. This pattern of work also tends to cause musculoskeletal complaints.

The next process is iron welding using an electric welding machine. Installation of electricity in each workshop is still very simple according to the capacity of the room and enough risk of short circuit. Welding is also often done with a sitting position, squat and stand where the workers adjust their position to the shape and surface of the iron to be connected through welding. In this welding process only a few workers who use glasses to protect the exposure of light from the welding. The work posture formed during the welding process is also not much different from the position of the body grinding where the workers do on the floor while sitting squat between the piles of iron and adjust his body with the shape and size of iron to be welded.

After the product is welded then the process of smoothing iron using hand grinding which is directly held and held close to pieces of connected iron. In the process of refinement is usually the workers grind with a standing position and performed in open areas either above the ground or using a work table. This is due to the smoothing process requiring higher precision in order for the smoothed iron joints to improve the quality of the resulting product.

The final stage of the finishing process is usually done in accordance with consumer demand. Generally produced products colored with colorful paint as 
Mahyuni, EL. et al. The Pattern Of Safety And Health Work To Prevent Musculoskeletal Disorders...

needed. In the process of iron painting begins by cleaning and smoothing iron dust from the remnants of welding by using sand paper. Work posture during both of these processes is also done in a squatting or standing position and not using a mask.

Ergonomic work postures often cause complaints in the body known as musculoskeletal disorders. Musculoskeletal complaints are formed because of the attitude of static work or posture in continuity. Musculoskeletal Disorders (MSDs) are a set of symptoms related to muscle tissue, tendons, ligaments, cartilages, nervous system, bone structure, and blood vessels. MSDs begin with pain, numbness, tingling, swelling, stiffness, trembling, sleep disturbance, and burning which results in a person's inability to move and coordinate limb movements or extremities thereby reducing work efficiency and loss of work time resulting in productivity work decreases [14]

Musculoskeletal complaints are felt in 51 workers vary almost spread throughout the body. This is supported because the welding workmanship pattern is still done manually. The most high complained is on the shoulders, arms, waist, knees and calves. This is due to the squat position that always experienced welder workers on Jl. Mahkamah could be seen in the following table:

Table 1. Musculoskeletal complaints on welding workers at Jl. Mahkamah

\begin{tabular}{|c|c|c|c|c|c|c|c|c|c|c|c|c|c|c|c|c|c|}
\hline $\begin{array}{c}\text { Muskulo skelets } \\
\text { System }\end{array}$ & \multicolumn{8}{|c|}{ Score } & $\begin{array}{c}\text { Muskulo skelet } \\
\text { System }\end{array}$ & \multicolumn{8}{|c|}{ Score } \\
\hline Upper neck & 1 & 31,4 & 1 & 31,4 & $1\}$ & 35, & 1 & 2,0 & Necklace & 11 & 31,4 & 11 & $19, \mathrm{t}$ & 2 . & 41,2 & 4 & 7,8 \\
\hline Left shoulder & 2 & 45,1 & 1 & 33,2 & 9 & 17,6 & 2 & 3,9 & Right shoulder & $1:$ & 29,4 & 11 & $21, \epsilon$ & $2:$ & 45,1 & 2 & 3,9 \\
\hline Upper arm left & 2 & 54,9 & 1 & 29,4 & 7 & $13, i$ & 1 & 2,0 & Back & 6 & $11, \varepsilon$ & $1<$ & 27,5 & $2 !$ & 58,6 & 2 & 3,9 \\
\hline Upper arm right & 1 & 37,3 & 1 & 33,2 & 1: & $21, \epsilon$ & 4 & 7,8 & Waist & 5 & 9,8 & $1:$ & 25,5 & $2 \imath$ & 54,5 & 5 & 9,8 \\
\hline Pinggul & 1 & 31,4 & 1 & $37, ?$ & $1:$ & 25,5 & 3 & 5,9 & Buttock & $2:$ & $49,($ & 1" & 33, & 9 & $17, \mathrm{C}$ & 0 & 0 \\
\hline Left elbow & 2 & 52,9 & 1 & 29,4 & 9 & 17,6 & 0 & 0 & Right elbow & $1<$ & 27,5 & $2 ?$ & 43,1 & $1 /$ & 27,5 & 1 & 2,0 \\
\hline Left under arm & 2 & 51,0 & 1 & $33, ?$ & 8 & $15, i$ & 0 & 0 & Right under arn & 1'. & 23,5 & 2: & 45,1 & $1:$ & 29,4 & 1 & 2,0 \\
\hline Left hand wrist & 2 & 43,1 & 2 & 39,2 & 7 & $13, \pi$ & 2 & 3,9 & Right hand wris & $1:$ & 29,4 & $2:$ & $49, \mathrm{C}$ & 11 & 19,6 & 1 & 2,0 \\
\hline Left hand & 2 & 45,1 & 1 & $33, ?$ & 11 & $19, \mathrm{t}$ & 1 & 2,0 & Right hand & $1:$ & 29,4 & 21 & 39,2 & $1{ }^{\prime}$ & 23,6 & 4 & 7,8 \\
\hline Left thigh & 2 & 54,9 & 1 & 31,4 & 6 & $11, \varepsilon$ & 1 & 2,0 & Right thigh & 21 & 41,2 & 2: & 45,1 & 4 & 7,8 & 3 & 5,9 \\
\hline Left knee & 1 & 37,3 & 2 & 47,1 & 7 & $13, i$ & 1 & 2,0 & Right knee & 11 & 31,4 & $2 ;$ & 43,1 & 11 & $19, \mathrm{t}$ & 3 & 5,9 \\
\hline Left calf & 1 & 29,4 & 2 & $52,$, & 9 & 17,6 & 0 & 0 & Right calf & 1" & 33,2 & 2: & 45,1 & 9 & 17,6 & 2 & 3,9 \\
\hline Left ankle & 2 & 51,0 & 2 & 41,2 & 4 & 7,8 & 0 & 0 & Right ankle & $2:$ & 43,1 & $2 ;$ & 43,1 & 7 & 13, & 0 & 0 \\
\hline Left leg & 2 & 56,9 & 1 & 27,5 & 7 & 13,7 & 1 & 2,0 & Right leg & 1: & 33,2 & $2<$ & 47,1 & 8 & 15,7 & 2 & 3,9 \\
\hline
\end{tabular}

Source: $0=$ normal; $1=$ little hurt; 2 = pain; $3=$ painful 
Mahyuni, EL. et al. The Pattern Of Safety And Health Work To Prevent Musculoskeletal Disorders...

Based on the pain complaint of musculoskeletal that feels by welding worker at Jl. Mahkamah could divide in MSDs risk categories that explained at the table.

Table 2. MSDs Risk Categorize at Welding worker Jl Mahkamah

\begin{tabular}{ccc}
\hline MSDs Risk Categorize & Frequencies & Percentage \\
\hline Low & 21 & 41,2 \\
Middle & 27 & 52,9 \\
High & 3 & 5,9 \\
Total & 51 & 100 \\
\hline
\end{tabular}

The complaints experienced by the dominant welding workers are in the moderate category $(52.9 \%)$ in accordance with the research done on the welding workshop X [15], where the moderate category generally leads to compliance with the degree of weight.

Based on the above table, the risk of MDSs experienced by workers need to be taken as a preventive measure. MSDs disease is a chronic disease that takes a long time to develop and manifest. The longer it works the longer the workers are exposed to the risk of MSDs [16].

To reduce the risk of developing MSDs that can be experienced by welding workers, the workers are trained and encouraged to do light stretching for 2-3 minutes by stretching the sick body while working. After work the worker can do ergonomic exercises for 10-15 minutes before heading home. This gymnastic activity is conducted jointly in the workplace and some workers' opinions state that with the ergonomic gymnastics exercises to know the parts of the body that are sick and able to self-assess its working patterns so far. This is a good achievement where awareness has emerged from workers realizing that during their work has demonstrated unsafe and unhealthy static work patterns.

Based on complaints of pain initially felt in the body, workers acknowledge experiencing pain loss initially felt and pain in the body decreased approximately $67 \%$ from previous pain. Workers also feel changes in blood and muscle movements that are better than ever. This suggests that ergonomic gymnastics is one of the best preventive measures in reducing musculoskeletal complaints due to unsafe and unhealthy work patterns.

\section{CONCLUSION}

The pattern of occupational safety and health work to prevent musculoskeletal were doing the streching relaxation and gymnastic activity. The ergonomic exercise and relaxation could decrease the musculoskeletal disorders at the welding worker in Mahkamah Medan in 67\%.

Recommended to the host of welding informal industry to arranged their work time for implement the ergonomic exercise in daily to decrease the musculoskeletal disorders at welding process.

\section{ACKNOWLEDGEMENT}

On this occasion, the researchers would like to thank Mr. Samosir who is the owner of CV Nauli welding business who has cooperated and supported the implementation of this research. We also thank to the Head of Subdistrict of Mosque who has given permission to implement this activity. This gratitude is also delivered to all the welding workers who are on Jl. Mahkamah in this study could prevent disease complaints especially musculoskeletal disorders with sustainable ergonomic gymnastics. 


\section{REFERENCES}

1. Himpunan Peraturan Perundangundangan Keselamatan dan Kesehatan Kerja, Kementrian Ketenagakerjaan RI, Direktorat Jenderal Pembinaan Pengawasan Ketenagakerjaan dan Keselamatan dan Kesehatan Kerja Tahun 2015

2. Sedarmayanti, 1996, Ergonomi untuk Produktivitas Kerja. http://www.belbuk.com/tata-kerja-danproduktivitas-kerja-p-4760.html.(Citaced at 29 September 2017)

3. Herlina, J.Evaluasi Stasiun Kerja dan Postur Kerja pada Bagian Pengelasan Ditinjau dari Faktor Ergonomi di UKM Logam Jalan Mahkama Medan, Medan : Tesis Postgraduate Program of Public Health, USU 2006

4. Sonawan, Hery dan Rochim Suratman, Pengantar untuk Memahami Proses Pengelasan Logam, Penerbit Alfabeta, Bandung, 2003

5. Annasyatul U., Kurniawati, Sonya H., Sri., R.I., 2008, Buku Pedoman Pelaksanaan Kesehatan dan Keselamatan Kerja untuk Praktek dan Praktikum, FKG - Airlangga, http://www.fkg.unair.ac.id/filer/buku\%2 Opedmn\%20K3PSTKG.pdf

6. Dwi Sandi bakhtiar, M. Sulaksmono, Risk Assessment Pada Pekerjaan Welding Confined Space di Bagian Ship Building PT. DOK dan Perkapalan Surabaya, The Indonesian Jounal of Occupational Safety and Health, Vol. 2. No.1 Jan-Jun, 2013; 52-60

7. Canadian Center For Occupational Health \& Safety.Radiation and the Effect On Eyes and Skin. Canada : Canadian Goverment. 2008

8. Agus Rubiyanto, Pengembangan Nano Fotonik dalam Perspektif dan Inovasi Teknologi, Departemen Pendidikan Nasional Institut
Teknologi Sepuluh November, Surabaya, 2006

9. Ronny Tuhumena, Rudi Soenoku, Slamet Wahyudi, Perancangan Fasilitas Kerja Proses Pengelasan yang Ergonomis (Studi Kasus pada bengkel PT. Aji Batara Perkasa), JEMIS Vol2. No.2 tahun 2014, ISSN 2338-3925

10. Departemen kesehatan RI, 2006, Glosarium data dan informasi kesehatan RI.

www.depkes.go.id/download.php/file/pus datin/glosarium-2006.pdf. access at 19 April 2017.

11. Badan Pusat Statistik, Profil Jalan Mahkamah Medan Kelurahan Mesjid Medan Kota, 2016 www.bps.go.id

12. Eli Mas'idah, Wiwiek Fatmawati, Lazib Ajibta, Analisa Manual Material Handling (MMH) dengan Menggunakan Metode Biomekanika untuk Mengidentifikasi Risiko Cidera Tulang belakang (Musculoskeletal Disorder) (Studi Kasus pada Buruh Pengangkatamn Beras di Pasar Jebor Demak), Jurnal Sultan Agung, Vol. XLV Np. 119 September-Nopember, 2009

13. Rian Yuni Kurnianto, Mulyono. Gambaran Postur Kerja dan Resiko Terjadinya Muskuloskeletal pada Pekerja bagian Welding di Area Workshop Bay 4.2. PT. Alstom Power Energy Systems Indonesia, The Indonesian Journal of Occupational Safety, Health and Environment, Vol 1. No.1 Jan-April 2014; 61-72.

14. Tarwaka. Ergonomi Industri Dasar Dasar Pengetahuan Ergonomi dan Aplikasi di Tempat Kerja. Edisi II. Harapan Press. Surakarta, 2015

15. Brianti Dofina, Erwin Dyah Nawawinetu, Beberapa Faktor yang Berhubungan dengan Keluhan Subjektif MSDs Pada Bengkel Las X, Jurnal Penelitian AKBID Mandiri Gresik 2016

16. Tarwaka, Ergonomi untuk Keselamatan dan Kesehatan Kerja, dan Produktivitas, Surakarta: UNIBA Press, 2010. 